\title{
Convergence of Biology and Gender Identity: A Study of Toni Morrison's The Bluest Eyes
}

Dr. Vanamala S.M.

Associate Professor

Department of Studies in English

Sir M Vishweswariah Post- Graduate Centre

University of Mysore

Mandya, Karnataka, India

vanamalasm861@gmail.com

\begin{abstract}
The concept of gender and the related practices are born at the intersection of biology and politics. Biological markers; physical, physiological and psychological are politicized for hierarchical positioning of man and woman. The nexus between biology and politics has also generated the notion of 'immutability' of woman's 'gendered self'. Women too, having interiorized the inferiority of the self unquestioningly and have shown little inclination to redefine her-'self' after having accepted the nature's role in her physical and physiological formation. The inability for better 'self' definition is also due to the failure to distinguish the exact point of confluence between biology and politics in the socially ascribed gender identities. Caught in the imbroglio woman has suffered crippled social and psychological consequences and the same is well substantiated in the novel The Bluest Eye by African American writer Toni Morrison. The women characters in the novel are paradigms of real life situations. While some do acutely suffer from social and psychological deprivation having interiorized the inferiority of their biological markers, others handle affirmatively the socially
\end{abstract}


ascribed deprivations of their physical self by understanding the nexus between biology and cultural politics. The novel successfully explores the fact that distinct anatomical difference between man and woman or the biological identities of humans should not be the cause or source of discriminatory practices. Or in other words the novel denies the inferiority of woman as something hermetically sealed and that social factors; advantages of birth (like race and social class), socio-cultural pressures, cultivation of mental culture and many more are of great consequence for both the formation of 'positive self- identity' by woman and for challenging of gender significations.

Keywords: Biological Markers, Social Ascription, Gender Significations, Social Shame, Psychological Deprivation, Self-Hood.

On studying human history we realize that hierarchical segregation of humanity in the name of differences of varied kinds seems indispensible. With the origin and development of science, the politics of segregation has used the findings of science to justify superior/ inferior claims. The propagators of differential politics always overlooked the fact that great stalwarts of science like Darwin and others though talked of differences yet never mentioned hierarchical relationship amongst different categories especially the male and female categories. They went on roping in scientific investigations, biological discoveries and anthropological findings as proof enough for asserting hierarchy amongst different sexes. Different identities like ethnicity, religion, nationality, language etc were all affected by the differential politics and the worst affected was the relativity of man and woman that resulted in gender practices; where the inferiority of women to that of men is vehemently believed in and asserted. I.Q tests or intelligence measurements tests claimed as scientifically worked out were quoted to prove the inferiority of woman to man. Or in other words I.Q tests or intelligence measurement tests were given immense predictive value to assert the superiority of men performance capability over that of women overlooking the fact that I Q Tests have 
been disputed a lot at different stages. Also the fact that the founding fathers of the human sciences like Anthropology and Biology did not refer from gender viewpoints were least considered. Linnaeus who wrote Systema Naturae (Nature's System) and other savants were least inclined to ascribe superior / inferior hierarchical relationship amongst different sexes of whatsoever species more importantly the humans. Instead they insisted that it was not possible to differentiate between people/ sexes in superior/inferior denominations. Again the promoters of gender politics ignored the findings of the science that asserted and promoted 'mental culturing and enhancing of intelligence' in humans by varied cultivation (of skills) modalities. Social factors, such as the advantages of birth, race, class, nationality and cultural pressures of other kinds too will decide acquisition of intelligence was overlooked in gender/racial practices. IQ as a measure was employed to assert female intellectual inferiority to male category. Ironically in 1905 Alfred Binet who introduced the first intelligence test neither believed that intelligence was an inherited capacity nor that it was fixed. He said "we must protest and react against this brutal pessimism" to oppose the notion of "innate fixed intelligence'. But the attempt to use IQ as a measure of civilizational attainment continued and its application to assert male intelligence superiority over that of female intelligence was also promoted. Cyril Burt who established the genetic base of intelligence neglected the factors of social, economic, familial and other causes as of little consequences in the matter. When Noam Chomsky showed that social class, parental income, type of schooling and several other factors correlated even more in deciding intelligence of an individual he was questioning the idea of 'innate fixed intelligence'. But his claims were disregarded and greeted with cries of 'ideological biases'. There was also the strong faith in the idea of intelligence as an intrinsic quality that is inherited or genetically determined. Thus women who were thought of as intellectually inferior to men, were believed to have inherited the mediocrity and thus were forever doomed not to be able to overcome their biological identity 
as carriers of lesser intelligence over that of men. Later the structures of society or the so called social institutions and organizations were roped in and strategically made to work as instruments promoting gender prejudices and exploitations. Comparatively women were quoted as having lesser intellectual capability over that of men and weaker muscle power to that of men and her emotionality was considered inferior to rational/reasoning capabilities of man. But today authorities of science have claimed EQ (Emotional Quotient) as equally deciding an entity for successes like IQ.

The biological self of woman thus is politicized to deny the egalitarian status and to reduce her to the status of social non-being; powerless and without honour. Many biological aspects; physical markers that includes sex organ, muscle power, strength, stature and height, intelligence, emotions, and certain physiological functions and psychological dispositions etc. are quoted to justify not only the difference but also hierarchy between man and woman. The most ironical and dangerous results of such biological justification is the "notion of immutability or irreversibility' it attributes to women inferiority. Cultural constructs though can be deconstructed, the same is said not possible with the aspects of nature/biology. Biological claims thus doom women to their gendered self forever as it is asserted that individuals are not able to overcome what is inherited or nature ordained. Feminists argue that biological justification or utility of science to authenticate gender practices mainly help gender perpetrators to enact oppression in a climate of moral safety. Perpetrators justify the act of oppression of women by patriarchal believers with the following moral claims; "when the inferior comes into contact with the superior, thus getting the opportunity of selfimprovement, by emulation." Such justification makes the prejudiced person not only secure in his beliefs but also frees him/her of guilt and allows him to avoid the self-opprobrium of having behaved in an entirely inhuman way with a fellow human being(woman). 
Against the hitherto made observation the paper aims to discuss how gender norms sustain undeterred existence because of the correlation of biology and social practices and how they have crippling social and psychological consequences for women. This nexus not only does assert man -woman relation as encoded in differential power politics but also gives abundance of opportunities for a patriarch to control woman in a decisive way. On the other hand justifications of biology influences woman to accept her inferiority ungrudgingly and condition her to make changes in her perception of her own interests. Once ascertained biologically, social institutions and organizations take up the responsibility of further popularizing women inferiority and thus contributing to the endemic exploitation of women. The other area with noteworthy role in the matter is the established discipline of psychology which early on got interested in the areas of character and personality types and their development in terms of intelligence. Theories of psychology too have asserted women difference to men and at times have asserted lesser functional capabilities in women compared to men. The use of sciences to justify gender practices or to authenticate the division of humanity in binary opposition of superior/inferior has fetched truth value to differential politics. Further harm is imposed in talking about women as one group of descent or category sharing common features. Describing them more in terms of group and less as individuals has further harmed women identity in failing to recognize their respective distinctness. Therefore the need of the hour is to recognize, identify and decipher this nexus between biology and woman identity before enough harm is perpetrated. The other responsibility is to make a positive use of biological facts/science to disclaim any superior/ inferior relational meanings between sexes; fe/male

Biological science and its interpretation of anatomical distinctness between male body and female body were well used to prove difference between man and women but the fact that it never made claims of hierarchical relation was underplayed. Gender and the related 
gender practices lack inherent truth value not only for the reason that biology never mentions grading and also for the very reason gender beliefs are born at the intersection of biology and politics; fact and concocted facts. What an anthropologist said as to the limitation of the claims of hierarchical discrimination of one set of people from another in terms of nationality/culture hold good to gender discrimination as well- "There are nations more susceptible of cultivation, more highly civilized, more ennobled by mental cultivation than others-but none in them nobler than others. All are in like degree designed for Freedom . ..” The phrase "susceptible of mental cultivation" is indeed promising and affirmative of change and reversal of grades and also implies that it is wrong to perceive the superiority of man over woman as hermeneutically sealed. Gender and racial practitioners have justified their claims quoting biological findings and the words of scientists like Stephen Gould that IQ tests has been (mis)used to infer differences among men and women to the benefit of the group in power was little cared for. To make biology a witness as to the rightfulness of gender practices has in turn imposed 'biological determinism' and 'biological reductionism' resisting possibilities of change or reversals for women.

The interesting thing about gender is that it is used as most precise a category as if there is no way of changing one's identity. But even a few moments' of careful scrutiny reveals gender to be precisely opposite. It is one of the most slippery concepts that one do come across. It's slippery quality comes from the very aspect that it was born precisely at the intersection of science and politics. Some of the biological aspects are put to political use to reverse egalitarian possibilities and this tendency is what is often described as biology disguised as politics. Gender is Janus-faced in that gender simultaneously refers to political and biological facts and it is this simultaneous reference that gives gender its slippery quality. What this means in practical terms is that it allows us to retreat behind the science of biology when the politics of gender are questioned and vice versa. But the ironical aspect of the 
whole affair is that the findings of science have been little used to deconstruct the constructs of prejudices against women and thereby subdue the politics of discrimination.

Debates in social sciences and humanities today do consider it as important to relate human biology with human culture to understand gender related politics and to deconstruct the same. To know why men and women behave differently or in a particular way in a given context, the knowledge both of biology and the sociocultural constructions that are governing them is very essential. The approach signifies an interdisciplinary effort and provides substantial justification both to grasp politics of heterogeneity and to dehierarchize the same. The fact that biology has come under the sway of human knowledge and institutions of human society; the 'socialization of nature', justifies the relating of these two pedagogies and also counter the reality of biological determinism of women inferiority. Genetic science that hitherto advocated that women and men are genetically coded the way they behave (asserting biological determinism) has now changed stance asserting the importance of environmental factors in moulding behavior/characters of individuals. The argument is that the disposition of an individual and his/her behaviour are results of the interaction between genetic and environmental factors. That is, genes and other biological factors interact with the environment in multifactorial, non-additive way to produce various outcomes for individuals' behavior and disposition. Environmental aspects which include the social and cultural aspects of human life can influence biological developmental outcomes. Bryan Turner's claim that we live in a somatic society, that is, one in which 'major political and personal problems are both problematized within the body and expressed through it ascertain the same. He means to say that rather this is 'a body worked over by culture.' Or in other words in most radical claim 'this is a body constructed by the forces of culture and that a sense of the 'self' or 'body' is no longer unitary but is characterized by fragmented, plural and shifting identities, i.e., the " body as a pre- social, pre- cultural object" is thought of as non-existent.' The best 
example for empirical manifestation of a cultural concern with the body is best proved by regimes of diet, exercise, and cosmetic surgery and discourses that successfully exhort us to shape and aestheticize the body to fit cultural norms. Evolutionary biology too explains human organism and the evolution as an outcome of chance and environmental adaptations. Problems of psychological distress or mental deprivation are both biochemical and cultural. The roots of depression planted in genetic and biochemical disposition are intertwined as well with family trauma/s. Indeed one of the most fascinating aspects of current research is the evidence that personal experience, including the way we think can alter the biochemistry of the brain. The result is the treatments of depression are currently achieved both through a combination of anti-depressant drugs and psychotherapy.

Medical science which until yester years had treated the body as a fixed entity and had tried to locate the sources of disease only in the pathology of human tissue; "biological reductionism", has in recent times stressed the importance of body-culture relativity. In the context of contemporary western culture, a more holistic understanding of health practice has begun to emerge called as bio-psychosocial model of medicine. Health promotion extends the processes of medicalization into cultural organization and lifestyle management. Thus we are exhorted, urged and disciplined into adopting the `right` healthy attitude towards our bodies. Illness is a sign of moral and personality weakness indicative of a lack of self-control and moral fortitude. It has become apparent that ill health is a consequence of what we eat, where we work, levels and types of exercise and the patterns of our thinking (generated in our childhood experiences), and so forth. Thus the latest bio-psychosocial model of the medicine extends their focus from the isolated body to bodies in environmental contexts. Thus we are exhorted, urged and disciplined into cultural organization and life style management. Thus disciplined we are exhorted, urged, disciplined into adopting the 'right' healthy attitude towards our bodies. This means that health promotion extends the process of medicalization 
into cultural organization and life style management. We are expected to give up smoking, abstain from illegal drug use, keep fit eat the right food etc. In some quarters illness is a sign of moral and personality weakness indicative of lack of moral fortitude.

Further 'gene's eye' view of evolution by Richard Dawkins argue that organisms mediate the relationship of genes to the environment. That is, genes in the bodies that are good at surviving and reproducing are those that build bodies and traits and that which gather cumulative advantage in the environment. Further the roots of emotional response are considered both as biochemical and culturally mediated. Emotional states have their roots in cultural conditions or emotional responses are socially constructed and hence it is important to understand the way emotions are generated and comprehended. Further the structure of our emotional past overlays an interpretative net on the present. More dramatically childhood traumas lay down 'emotional memories that condition future associative responses'. Explanations for depressions and its associated social difficulties lie in a combination of biological, psychological and cultural analysis. Mental illness like the explosion of anxiety suggests social and cultural causes. Feelings of anger, low self- esteem and powerlessness are rooted in family trauma and a loss of social and cultural connections. Difficult childhood memories or experiences are commonly reenacted in adult relationships. The roots of depression are planted in genetic and biochemical disposition intertwined with family trauma. Indeed one of the most fascinating aspects of current research is the evidence of that personal experience, including the way we think can alter the biochemistry of the brain. The best result is the treatments of depression are currently achieved through a combination of antidepressant drugs and psychotherapy. Attention to these developments stressing the relativity between human biology and human culture aids the feminists to challenge the claim that social inequality of the sexes is wholly grounded in biology and thus unalterable. Influenced by poststructuralist and postmodern thought feminists have argued that sex identity and its 
related gender identity for women are social and cultural constructions that are not to be explained in terms of biology and argue that 'femininity' and ' masculinity' are not universal and eternal categories but discursive constructions and are ways of describing and disciplining human subjects (especially women). Femininity and masculinity which are a matter of how men and women are represented are held to be sites of continual political struggle over meaning. Ironically feminist biologists have tried to expose how many a biological experiments are controlled by gendered notions resulting in faulty findings. Fifty years of cultural change in relation to sex/ gender has demonstrated that traditional gender role is not immutable or fixed and that transformation is possible. Feminism that aims to deconstruct patriarchal representations of women or aims to prove that men to women and vice-versa relational aspects are thoroughly saturated with power relations asserts that 'sex' is a fundamental and irreducible axis of social organization that has been propagating through its whole range of social institution and practices the subordination of women to men. There are indeed essential distinct difference between men and women and these fundamental differences are variously interpreted as cultural, psychic and biological. Pursuits of the interests of women involves not only in achieving their social equality with men but also in women's realization of their fundamental difference from men and perceiving this difference not in terms of hierarchy.

The present paper aims to study gender issues and the related power politics of patriarchy as depicted in the novel The Bluest Eyes against the hitherto made substantial discussion of the interrelationship between biology and gender beliefs. The novel The Bluest Eyes is particularly chosen to prove the strategically worked out interdependency of biology (body) and gender beliefs. The analysis ultimately aims to prove that both gender and racial identity and their inferior connotations are contingent upon cultural meanings that in reality lack truth value and hence escape 'biological determinism'. Unlike ethnic and national 
identity gendered identity though is universal yet is unstable and is an identity temporarily stabilized by social practices. The paper substantiates the above argument by analyzing the women characters in the novel The Bluest Eye by African American writer Toni Morrison. The novel portrays both the dangerous threats of racial and gender practices and also explores the nature of victimization and modes of countering the same. Some women characters in the novel are paradigms of 'affected women' victimized by gender and racial practices. These women are shown as suffering from acute social and psychological deprivation having interiorized the inferiority of their biological markers; others handle affirmatively the socially ascribed deprivations of their physical self by their capacity to rationalize the nexus between biology and social politics. The novel has enough instances of both the negative and positive use of woman subjectivity and agency either for perpetrating the politics of gender or deconstructing the same respectively. In the novel The Bluest Eye Toni Morrison grasps the idea that anatomical norms of woman are politicized through social ascription and the role of women subjectivity and agency play a role in evolving their gendered identity or resisting the same. Thus the novel successfully purports the idea that difference in man-woman anatomy ascertains distinctness and attributing this distinctness to ascertain inferior superior polarity is both wrong and is a chimera. This only means that to see the division of humanity as hermeneutically sealed is wrong and social factors; advantages of birth (race and social class), socio-cultural pressures, cultivation of right mental culture and many more are of great consequences. Stuart Hall hence claimed that it is in positive "self-identity formation" that social ascriptions of gender/racial identities can be best challenged and the inherent truth value of the same can be best questioned.

The Bluest Eye was written by African American novelist Tony Morrison in 1970. On analysis of Toni Morrison's The Bluest Eye we understand how the anatomical norms of woman are politicized by racism and the same is perpetrated through social ascription. The 
novelist also purports the role of women subjectivity and agency in both evolving ones' gendered/racial identity or in resisting the same. The novel centers on the life of many African American women who live life carrying the double burden of being colonized and subordinated by imperial powers and also by colonial native men. Of the many women, an African American girl named Pecola and her mother Pauline Breedlove are important as they are paradigms of absolute victimization of the nexus between biology and gendered practices. Pecola is an example of affected childhood and her's is an instance of lost childhood. She lives in a society where the mannerisms of the white community and the white skin, blue eyes and blonde hair alone are acknowledged with lots of respect and is considered as the beauty standard. Pauline the mother of Pecola too has interiorized these beauty standards and hence hates her daughter whom she thinks as ugly because of her dark skin. She therefore extends very little positive assurances for Pecola to feel confident and happy. The mother-daughter duo Pauline and Pecola think of themselves social misfits and suffer from acute inferiority complex as they don't carry the beauty standards white society propogates. Pecola is the worst affected being a child and without resources to rationalize her negativity. She suffers intensly when illtreated and little loved even by her mother and other members of her own community. She is always unhappy as her desire for fair skin, blue eyes and blonde hair is forever denied to her. Never to have these is never to have respect, love, esteem and recognition in the society. From her community she partakes her mannerisms and from her race her biological body which never changes however hard one does try. These attributes are nothing wrong as such but for the reason that she lives in a society where both her mannerisms are disrespected and her skin colour and other features of nose and skin texture are considered as ugly. It is not just Pecola and her mother Pauline Breedlove but even the male members that include Pecola's father Cholly Breedlove and brother Sammy suffer from regret and shame at their very existence. The whole of the family is victimized by racial 
taboo and thus " 'a family'; a culturally conceived entity that should serve as a supportive unit for survival and happiness for its members turns out to be a thing much detested." Cholly proves a bad husband, bad father and involves in actions that verge on insanity like burning down his own house and sexually abusing his own daughter. Interestingly the author traces the motives of his action as having its source in his "confused self that cannot distinguish the difference between love and hatred." After raping his daughter a second time, he flees, leaving her pregnant. This case of filial incest ; morally outrageous kind is attributed to the lost and infested childhood of Cholly than to any kind of 'bad guy' identity. In his formative years as a child and adolescent he had never enjoyed love and had grown up only with shame and disrespect. His mother also a victim of the taboos persisting in a society that practices racism and gender stereotyping had abandoned him on the very day of his birth and he had grown up like an orphan. Therefore he is in a way unaware and insensitive to refined emotions of love between husband-wife, father-daughter which a civil society celebrates. The only surviving impulse in him is the animal-self. Therefore Cholly had shown Pecola the only love he was capable of namely 'animal love' that results in raping his own daughter. Or in other words the 'father- daughter love', the most ennobling kind, Cholly is unable to experience and the only kind of love he can express is that of the crude kind; lust without love. This proves that the animal in Cholly is alive and the civilised human being has never replaced the animal in him. The refined and noble forms of love human culture inculcates are beyond his grasp for he personally had never experienced love of refined and exalted kind. Thus he becomes the best paradigm of the popular saying "we give back the society what we have received from it". The effect of unhappy existence has its repercussion even on financial sustenance of the family and Pecola's family live in impoverished condition. Her parents involve in constant fight both verbally and physically. 
The people thus born with the anatomical forms; dark skin with characteristic hair texture and nose shape, is forever confined to the margin in a society that thinks the physical norms of white skin, blonde hair and straight nose alone can mean privileged existence. Biological facts of cross breeding that allows the dilution of these traits are ignored and the fact that race identity has its source in environmental factors (as per theory of evolution) is intelligently ignored. The whole of Pecola's family is a case of affected or lost childhood due to their traumatic struggles as African-Americans living in a largely White Anglo-Saxon Protestant community of USA. None of them are capable of building a happy prosperous future. They never grow up into resisting the injustices of the society or 'the others' but are only successful in inflicting pain on 'the self' and the most vulnerable namely the immediate kith and kin. Pecola is continually reminded of what an "ugly" girl she is by members of her neighborhood, school community and her mother. So Pecola dreams of beautifying herself to have love and respect from the society. Pecola wishes for fair skin, blue eyes, and blonde hair; beauty standard that was perpetuated through the gifting of white, blue-eyed dolls throughout her childhood. The biological body of the Anglo-saxons; fair skin, blue eyes and blonde hair has been publicized as the 'standard beauty' and the African American women accepting the same and thriving to have it ironically signifies a struggle against 'Nature' or 'biological determinism' and hence is pre-destined to failure forever. In the character of Cholly Breedlove and the disastrous selves of the family members of Cholly Toni Morrison is projecting the risks discrimination can cause.

The other family in the novel is that of the Macteers who do belong to the same African-American community yet is able to outgrow inferior existence and the shame related to it by effectively countering the faulty social practices that politicized biological norms namely the anatomical body. Unlike the Breedloves they are capable of resisting the shame of existence society imposed on them for having different body features from that of the 
white. The adult Macteers are least affected unlike the Cholly couple and do evolve a happy family providing economic sustenance, love and security for their daughters. Hence Claudia and Frieda Macteer (of the same age of Pecola) are capable of happy existance and also can extend love for others. While the whole lot of adults look upon Pecola with disgust as an unlucky, shamed child molested by the biological father; a case of filial incest, Claudia and Frieda pray for Pecola's health and wish health and love for the baby in Pecola's womb. Healthy and protected upbringing saves them from falling prey to any kind of delusions like Pecola. Pecola's deep seated desire to experience love and respect expresses itself in yearning for white skin, blonde hair and blue eyes. She is neither guided by her parents (who are misguided themselves) nor able to understand that biological norms of the body cannot be changed. She suffers from the delusion that she has been granted with the blue eyes and thinks that people's staring at her was in appreciation of her blue eyes (in reality people stare at Pecola's shame of being raped by her own father)..

Scientifically it is proved that emotional states; normal or pathological have their roots in cultural conditions or in other words emotional responses are socially elicited and hence it is important to understand the way emotions are generated and comprehended. Further it is psychologically believed that the history of our emotional past overlays an interpretative net on the present. More interestingly it is believed that childhood traumas lay down 'emotional memories that condition future associative responses'. Difficult childhood memories or experiences are commonly reenacted in adult relationships. Explanations for depressions and its associated social difficulties are rooted in a combination of biological, psychological and cultural analysis. Feelings of anger, low self- esteem and powerlessness are rooted in family trauma and a loss of social and cultural connections. Pecola and her parents in The Bluest Eyes are a fine instance or precedence of the above explanation describing the interdependency of emotion and culture. Pecola and her parents in their 
disaster represents the plight of all those who are burdened to carry the baggage of both gender and racial prejudice: both of which involves the abuse and misinterpretation of the biological body. It is therefore crucial to understand the nexus worked out strategically by gender perpetrators between biology and culture to assert the inferiority of woman over man and counter the same to save women from suffering serious pitfalls. Biology; science that asserts difference between man and woman, but never the hierarchy needs to be understood and used as the saving grace for women by scholars well rooted in the science of biology and social sciences/humanities specially interested in gender studies. 


\section{References}

Morrison Toni. The Bluest Eyes: Harper Collins, New York, 1970

Duvall, John. The Identifying Fictions of Toni Morrison: Modernist Authenticity and Postmodern Blackness. Palgrave Macmillan.2000

Roopali Sircar. The Twice Colonized: Women in African Literature: Creative Books. New Delhi.1995

Chris Barker. Cultural Studies; Theory and Practice: Sage Publications. New Delhi. 2000.

Zutshi Somanath. Biology as politics: Seagull Books Private Limited. Calcutta.2004 